\title{
Ambivalente afsløringer - jobkonsulenters erfaringer med diagnosers betydning for psykiatribrugeres deltagelse på arbejdsmarkedet
}

\author{
Søren Salling Weber
}

Forskelssætninger er betydningsfulde og legitime i allokeringen til arbejdsmarkedet i et differentieret samfund. De bidrager både til udnyttelse af samfundets arbejdskraft og til kvaliteten af den enkeltes arbejdsliv. Forskelssætninger indgår samtidig i konflikter om ressourcetildeling og privilegier, og de kan danne grundlag for diskrimination. Denne artikel fokuserer på den modsætningsfyldte funktion af diagnoser i en specialiseret beskæftigelsesindsats for psykiatribrugere. Afsættet er jobkonsulenternes arbejde med at støtte psykiatribrugere på arbejdsmarkedet med metoden individuelt planlagt job med støtte. Målet med artiklen er, for det første, at vise empirisk, hvordan differentieringen af psykiatribrugere ud fra deres diagnose indgår i forhandlinger mellem professionelle, brugere og arbejdsgivere, hvilket er anledning til ambivalenser blandt jobkonsulenterne. For det andet at fremskrive en teoretisk begrundet analyse af psykiatribrugeres deltagelse på arbejdsmarkedet, som kan forklare jobkonsulenternes ambivalenser om at afsløre diagnoserne. Med afsæt i Nancy Frasers begreb om en bivalente kollektivitet viser jeg, hvordan afsløringen af diagnoserne har betydning for jobkonsulenternes deltagelse, status og relationer til brugere og arbejdsgivere - og dermed for deres muligheder for at understøtte psykiatribrugeres arbejdsmarkedsintegration. Afslutningsvis fremhæves nødvendigheden af at medreflektere både kulturelle og økonomisk forankrede marginaliseringsdynamikker i forståelsen af psykiatribrugeres situation.

Nøgleord: lighed i deltagelse; bivalent kollektivitet; støttet beskæftigelse; individuelt planlagt job med støtte; aktiv beskæftigelsesindsats

\section{Indledning}

Psykosociale problemer har sjældent været afsæt for offentlig støtte til beskæftigelse. I psykiatrien har fokus været på kvaliteten af behandlingen for patienterne. Og på beskæf- tigelses- og socialområdet har opgaven været at aktivere og sikre udsatte borgeres rettigheder (Bengtsson \& Ørkeby Gregersen, 2013; Bonfils, 2019). Kendskab til lovgivningen var den faglige vidensbase for at vurdere borger- 
nes situation. Det vanskelige var ofte: "to identify where they believe an individual applicant fits in the continuum between genuine barriers to work and personal willingness to work." (Møller \& Stone, 2013, s. 201). Diagnosen havde her en vigtig funktion: Den kunne bruges til at retfærdiggøre skønnet om tilkendelse af ydelser ved at adskille syge fra arbejdsduelige. Men netop derfor blev diagnosen ofte (kun) brugt til at begrunde antagelser om (manglende) arbejdsevne i de dominerende faglige forståelser. I de senere år er beskæftigelsesindsatsen blevet yderligere udskilt og institutionaliseret med fokus på sagsbehandling og aktivering, som foregår adskilt fra eventuelt rehabiliterende optræning hos anden aktør (Baadsgaard, Jørgensen, Nørup \& Olesen, 2012; Nielsen, 2015). Konsekvensen har mange steder været en endnu højere risiko for aktiveringsforløb med manglende viden om og støtte til ledige med komplekse behov (Larsen \& Andersen, 2019). Aktuelt er der samtidig voksende interesse i psykiatribrugeres muligheder for at arbejde. Politisk er der voksende pres for inklusion i uddannelse og arbejde (Larsen \& Larsen, 2017, s. 23), og i befolkningen er der en vis berøring med åbenhed om og vilje til at omgås mennesker, der oplever psykiske problemer. (Jacobsen, Martin, Andersen, Christensen, \& Bengtsson, 2010, s. 8). Inddragelse af menneskers psykosociale problemer i beskæftigelsesindsatsen kan altså udgøre et potentiale for bedre at imødekomme deres behov.

I denne artikel undersøger jeg de professionelles erfaringer med psykiatriske diagnoser i en specialiseret beskæftigelsesindsats for psykiatribrugere. Afsættet for artiklen er, at forskelssætninger, som diagnoser, kan få modsatrettede funktioner. Forskelssætninger er på den ene side uomgængelige, og i sorteringsprocesser er de nødvendige og legitime. De kan danne grundlag for anerkendelse - og derfor fremme solidaritet, social integration og lighed. Men forskels- sætninger kan også skabe tabu, stigma eller ringeagt. De kan disciplinere, og de kan opretholde, legitimere eller forstærke uligheder. Det er derfor centralt at inddrage et kritisk blik for magtudøvelse i analysen af forskelssætningers betydning. Ikke mindst i beskæftigelsesindsatsen, hvor de kobles til et arbejdsfelt med den samfundsmæssige funktion at allokere til et arbejdsmarked med modsatrettede interesser: De professionelle anerkender, hjælper, kvalificerer og motiverer deres klienter, men skal også (fra)sortere, fordele og disciplinere dem til arbejdsmarkedet (Offe, 1984).

Det empiriske afsæt for artiklen er jobkonsulenters ambivalenser om diagnosernes betydning for relationerne til arbejdsgiverne $i$ arbejdet med metoden individuelt planlagt job med støtte (IPS). Brugernes beslutning om 'disclosure', at fortælle arbejdsgiverne om deres diagnose, fremstår her afgørende for deres forløb. Jeg oversætter det til 'afsløring' for at fremhæve valgets karakter af et dilemma med omfattende, ofte utilsigtede, konsekvenser for jobkonsulenternes opgaver, position, status samt samarbejde og forhandlinger med arbejdsgiverne ${ }^{1}$. Jeg analyserer konsekvenserne ud fra en forståelse af psykiatribrugere som en bivalent kollektivitet: Diagnoser indgår i kampe for anerkendelse af og omfordeling af ressourcer til psykiatribrugere. Jobkonsulenternes ambivalenser forklares dermed ud fra diagnosernes betydning for deres muligheder for at begrunde brugernes behov, integrere dem på arbejdsmarkedet og sikre deres lighed i deltagelse.

I det følgende opridser jeg en diskrepans mellem en voksende optimisme om jobkonsulenters støtte til psykiatribrugere - og deres fortsatte underrepræsentation på arbejdsmarkedet. Derefter præsenterer jeg den teoretiske ramme, hvor diskrepansen analyseres ud fra en forståelse af psykiatribrugeres som en bivalent kollektivitet. Jobkonsulenternes ambivalenser om at inddrage diagnoserne 
i arbejdet med at udbedre diskrepansen forklares dermed ved, at psykiatribrugere er underlagt både kulturelt forankret ringeagt og økonomisk-strukturelt forankret marginalisering. Artiklens case, empiriske grundlag og metode præsenteres ${ }^{2}$. Analysen viser, hvordan brugernes beslutning om at afsløre deres diagnose påvirker organiseringen af jobkonsulenternes samarbejde og forhandlinger med arbejdsgiverne - og dermed deres deltagelse på arbejdsmarkedet. Afsløring af diagnoser er en forudsætning for, at jobkonsulenterne kan være med til at afklare, formulere, normalisere og legitimere arbejdstagernes behov på arbejdsmarkedet. Men de kobles også til økonomisk forankrede interessekonflikter med risiko for stigma, forskelsbehandling, sortering og eksklusion. Ud fra analysen argumenteres der afslutningsvis for, at en forståelse af psykiatribrugere som en bivalent kollektivitet udreder jobkonsulenternes ambivalenser: Begrebet forklarer, hvordan arbejdsmarkedets magtforhold og interessekonflikter komplicerer forhandlinger om betydningen af diagnoser i integrationsprocessen.

\section{Psykiatribrugeres forhold på arbejdsmarkedet}

Psykiatribrugere har længe været en arbejdsmæssigt marginaliseret gruppe. Psykiske problemer var før førtidspensionsreformen skyld i cirka halvdelen af alle langtidssygemeldinger og førtidspensioner, og under 30 år næsten $80 \%$. De har resulteret i flere langtidssygemeldinger end somatiske sygdomme med "statistisk indikation for, at sammenhoengen mellem mentale helbredsproblemer og sygefravoer er stoerkere for de mere alvorlige mentale helbredsproblemer" (Borg, Nexø, Kolte, $\&$ Andersen, 2010, s. 133). Efter et drastisk fald med reformen af førtidspensionssystemet i 2013, hvor 2469 blev tilkendt førtidspension ud fra psykiske problemer, er tallet steget stødt men stabilt, så der i 2018 var 5177 og i 20196553 nytilkendelser (STAR, 2020). En nyere undersøgelse af beskæftigelsessituationen for handicappede viser, at mennesker med psykiske problemer, sammenlignet med andre handicappede, har lavere beskæftigelsesgrad, oftere har længerevarende helbredsproblemer, søger mindre arbejde, oftere kommer i særansættelser og oftere har et ønske om at arbejde (mere). Konklusionen er, at "personer med en psykisk lidelse står med soerlige udfordringer i forhold til at komme i og fastholde beskaeftigelse." (Larsen \& Larsen, 2017, s. 19 jf. også 14, 52, 63, 120).

Aktuelt er der dog voksende interesse i offentlige jobkonsulenters potentiale for at integrere psykiatribrugere på arbejdsmarkedet. Med en kontekstualiseret, individualiseret støtte fra jobkonsulenter kan mange psykiatribrugere arbejde (Drake, Bond \& Becker, 2012). Jobkonsulenterne kan opstarte jobsøgningen, engagere og forpligte støttepersonerne i virksomhederne, give viden om brugernes behov, afbalancere pres og hjælp og optræde som problemløser og mægler i konflikter (Frøyland, Schafft \& Spjelkavik, 2019). På arbejdspladserne er psykiatribrugere den gruppe af beskæftigede handicappede, "hvor relativt flest angiver at have fået tilbudt og iværksat en eller flere indsatser af arbejdsgiveren (49,6 pct.)" (Larsen \& Larsen, 2017, s. 173). Samtidig oplever halvdelen "i høj grad", og yderligere en fjerdedel i "nogen grad", at arbejdsgivere og kolleger "tager tilstrækkeligt hensyn til deres handicap" (Larsen \& Larsen, 2017, s. 178). En dansk undersøgelse af arbejdsgivernes erfaringer med at inkludere udsatte borgere rejser spørgsmålet, om arbejdsevnen må forstås som en kontekstuel kapacitet, som kan udvikles ved at fjerne risici og skabe kontinuitet i ansættelsesforløbene: "Måske bliver arbejdsmarkedsparathed til i den konkrete relation, der udfolder sig mellem en person og en virksomhed, mens de ser hinanden an og loerer hinanden at kende." (Madsen, 
Søbjerg Nielsen, Ehrenreich, Habekost \& Ørnbøl,, 2016, s. 20). Åbenhed og dialog er en forudsætning for at tilpasse arbejdsprocesser og rammer til psykiatribrugernes behov (Akabas \& Gates, 2008). Undersøgelser peger altså på, at der er et vist potentiale $i$ at lade jobkonsulenter inddrage kolleger og ledelse på arbejdspladserne i at integrere psykiatribrugere.

En ny, norsk undersøgelse viser tilsvarende et stort potentiale for inklusion i, at offentlige virksomhedskonsulenter kan samarbejde med støttepersoner på virksomhederne, som, med tid, ressourcer og ledelsesstøtte, kan inkludere udsatte arbejdstagere. Undersøgelsen viser dog "utfordringer i spennet mellom NAVs [beskaeftigelsesindsatsens] taushetsplikt, arbeidsgivers taushetsplikt og kollegers behov for å vite noe om dem som kommer inn på arbeidsplassen." (Spjelkavik, Enehaug, Klethagen \& Schafft, 2020, s. 96). Udfordringerne kan forstås ud fra et behov for tillid, samt en risiko for stigmatisering, hvor man tilskrives stereotypiserede egenskaber med tab af status og sociale sanktioner til følge (Link \& Phelan, 2001). Psykiatribrugere bruger derfor "enorme ressourcer på at styre og kontrollere kommunikationen om deres lidelse" (Jacobsen, Martin, Andersen, Christensen \& Bengtsson, 2010, s. 6). Internationale undersøgelser viser, at næsten tre ud af fire tilbageholder informationen om en skizofrenidiagnose, to af tre forventer negative konsekvenser af diagnosen, og en fjerdedel mente diagnosen udgjorde en decideret forhindring for at få arbejde (Thornicroft, Brohan, Rose, Sartorius \& Leese, 2009). Nyere danske undersøgelser viser, at kun ca. hver fjerde med psykiske problemer føler sig godt hjulpet tilbage på arbejdspladsen efter en sygemelding, og "76,8 (sic) \% af medarbejdere med psykisk sygdom vendte heller ikke tilbage til samme arbejdsplads, hvilket kan afspejle manglende ledelsesmoessig og kollegial støtte" (Ladegaard, Thisted, Gensby, Skakon \& Netterstrøm, 2017, s. 101). Man kan blive aftvunget en forklaring for at få støtte, og et skift af arbejdsplads kan være at foretrække. I en anden undersøgelse oplevede $40 \%$ af de diagnosticerede stigma, og $65 \%$ selvstigmatisering på arbejdet (Mosegaard et al., 2018, s. 13). Uvidenhed, tabu og fordomme skaber altså risiko for et statustab med konsekvenser for selvforståelse og deltagelsesmuligheder, og det kan spille ind i overvejelser om at afsløre sin diagnose på arbejdspladsen.

Der er altså stigende interesse for jobkonsulenters samarbejde med arbejdsgiverne, hvor åbenhed og dialog er en vigtig forudsætning for tilpasning af stillingerne. Men samtidig er det veletableret, at inddragelse af psykiatriske diagnoser kan aktualisere fordomme og stigmatisering, og at der kan være modsatrettede interesser om afsløring af diagnoser på arbejdspladsen. Diagnosens betydning for jobkonsulenternes arbejde og brugernes forløb er imidlertid endnu ikke velbelyst. I denne artikel undersøger jeg derfor, hvordan diagnoser får betydning for jobkonsulenters arbejdsmarkedsintegration af psykiatribrugere. Artiklen bidrager dels ved at vise, hvordan inddragelsen af diagnosen skaber ambivalenser hos jobkonsulenterne, fordi det påvirker deres status, samarbejdsrelationer og muligheder for at støtte på arbejdspladsen. Dels analyseres ambivalenserne ud fra en forståelse af psykiatribrugere som en bivalent kollektivitet. Begrebet belyser, hvordan psykiatribrugeres diagnoser spiller sammen med de særlige konflikt- og magtrelationer på arbejdsmarkedet. Dermed belyses komplekse marginaliseringsdynamikker ved at gøre diagnoser til afsæt for jobkonsulenters arbejde i beskæftigelsesindsatsen.

\section{Psykiatribrugere som en bivalent kollektivitet}

Diagnoser indgår i stigende grad i hverdagssproget og i andre sociale rum end psykiatrien, ofte på uforudsigelige måder (Rose, 2019, 
s. 72-73). I min analyse tager jeg afsæt i jobkonsulenternes arbejdsliv, men sætter fokus på diagnosens samspil med arbejdsmarkedets krav som en specifik kilde til ulighed for psykiatribrugere. Arbejdet med diagnoserne forstås som genstand for dynamisk udvikling af mening og arbejdsidentitet $\mathrm{i}$ jobkonsulenternes arbejdsliv. Inddragelse af diagnoser i arbejdet er ambivalent: Det udgør både et sammenbrud, som kræver en restrukturering af erfaringer og mening i arbejdet - og en læringsmulighed, hvor nye kvaliteter opstår (Nielsen, 2018; Olsén, 2008).

For at forstå jobkonsulenternes ambivalenser omkring afsløringen af deres klienters diagnoser, inddrager jeg Nancy Frasers teori om bivalente kollektiviteter og lighed i deltagelse (Fraser, 1997, 2007, 2013). Fraser fremhæver, hvordan forskelssætninger er afsæt for at begrunde og legitimere behov - $\mathrm{i}$ særdeleshed i institutionaliseringen af støtte til udsatte grupper (Fraser, 1989, s. 303; Offe, 1984, s. 34). Diagnoser kan ændre positioner og problemforståelser og begrunde behov om støtte og tilpasning. Netop derfor bliver de også genstand for interessekampe og forhandlinger om ressourcer (Fraser, 2013, s. 55). Ambivalenserne afspejler disse kampe. Argumentet er videre, at kampenes karakter kan analyseres ved at forstå psykiatribrugere som en bivalent kollektivitet (Fraser, 1997, s. 22): De er, som gruppe, underlagt både manglende anerkendelse og økonomisk ulighed.

"Bivalent collectivities, in sum, may suffer both socioeconomic maldistribution and cultural misrecognition in forms where neither of these injustices is an indirect effect of the other, but where both are primary and co-original." (Fraser, 1995, s. 78).

Psykiatribrugere er kulturelt ringeagtede i et samfundsmæssigt statushierarki. Det indebærer dominans, forstået som manglende kontrol over de standarder, de evalueres ud fra, mang- lende anerkendelse, i form af usynliggørelse og tabuisering, og disrespekt, forstået som stereotypisering, stigmatisering og diskrimination (Fraser, 1997, s. 14). Psykiatribrugere er imidlertid også økonomisk marginaliserede; "confined to undesirable or poorly paid work or being denied access to income-generating labor altogether" (Fraser, 1997, s. 13) og genstand for udbytning på arbejdsmarkedet. Selv uden kulturel stigmatisering kan psykiatribrugere have vanskeligt ved at varetage stillingerne; arbejdets aktivitetskrav, indhold samt arbejdsdeling og -betingelser. En reel ligestilling vil kræve tilpasning for nogen. Bivalente kollektiviteter udmærker sig desuden ved, at de to uretfærdighedsformer er kompleks sammenvævede, gensidigt forstærkende og derfor genstridige at forandre (Fraser, 1997, s. 15,$137 ; 2013$, s. 102). Ambivalenserne kan forklares ud fra diagnosers modsætningsfyldte betydning for statuskampe og økonomisk forankret uretfærdighed.

\section{Metode}

\section{IPS: en ekstrem case på diagnosers betydning}

En række forhold gør IPS til en interessant case på muligheder og dilemmaer ved at lade diagnosen indgå i de professionelles arbejde i beskæftigelsesindsatsen. Jobkonsulenterne samarbejder direkte med arbejdsgiverne: De opdyrker, identificerer, formidler og forhandler ansættelser, og støtter brugerne i arbejdet. Diagnoser er omdrejningspunkt for organiseringen i IPS. Afsættet er, at langt flere med en 'svær' ${ }^{3}$ psykiatrisk diagnose kan arbejde (Drake, Bond \& Becker, 2012, s. 36). I forhold til en beskæftigelsesindsats domineret af bureaukratisk-administrative kategorier får diagnoser derfor stor betydning (Bonfils, 2019). IPS er brugerstyret. Ud fra forskning i recovery og retten til at deltage betones bru- 
gernes valgfrihed, autonomi, status, ansvar, motivation og ønsker for beskæftigelse (eg. Drake et al., 2012, s. 35pp, 99). Der arbejdes ud fra klienternes egne jobønsker - ikke hvad der bedømmes realistisk af jobkonsulenterne. Målet er ordinoer beskæftigelse - ikke de ellers udbredte ansættelser på divergerende vilkår (Larsen \& Larsen, 2017, s. 157). Mest centralt i denne sammenhæng skal brugerne selv beslutte 'disclosure'; om de vil fortælle om deres diagnose. Jobkonsulenterne følger brugerne og får derfor indblik i forløb med og uden afsløringer af diagnoserne. IPS giver gode arbejdsbetingelser. Jobkonsulenterne har 25 klienter tilknyttet og oplever større autonomi, kontinuitet og variation i arbejdet i IPS end i beskæftigelsesindsatsen. Forskningsmæssigt forankrede proces- og performance-evalueringer ${ }^{4}$ af beskæftigelsesgraden erstatter aktiveringer, økonomiske incitamenter, sanktioner og kontrol. "The special working conditions possible under IPS, compared to the somewhat more limited scope of action that is possible with conventional interventions, means that case-workers can directly and actively support the endeavors of individual participants." (Topor \& Ljungberg, 2016). Arbejdsbetingelserne giver jobkonsulenterne en større berøringsflade med jobsøgningsprocessen og diagnosens betydning. Arbejdsbetingelserne bidrager også til bedre resultater: Brugerne er generelt meget tilfredse med støtten, og $60 \%$ af dem er kommet i arbejde eller uddannelse, hvilket afspejler de store potentialer ved at udvikle beskæftigelsesindsatsen (Eplov \& Christensen, 2018). Som case gør direkte samarbejde med arbejdsgiverne, specialiseringen ud fra diagnoser, brugerstyring, valget om 'disclosure', gode arbejdsbetingelser og gode resultater IPS til et ekstremt indblik i psykiatriske diagnosers potentiale for at forbedre professionelles arbejde i beskæftigelsesindsatsen. Alligevel oplever de professionelle, at afsløringen af diagnosen kan være problematisk i forhandlingerne med arbejdsgiverne. Jeg tolker derfor jobkonsulenternes ambivalenser som en kritisk case: Når det er problematisk at inddrage diagnoser i samarbejdet med arbejdsgiverne i denne succesfulde indsats, så giver det antageligt indblik i dynamikker i integration af psykiatribrugere på arbejdsmarkedet, som kan være relevante for beskæftigelsesindsatsen i øvrigt (Flyvbjerg, 2006, s. 230; Yin, 2006, s. 38).

\section{Immanent kritik af en specialiseret støtte}

Empirien til casen er i forlængelse af tidligere undersøgelser (Bonfils, 2019; Eplov \& Christensen, 2018) genereret ud fra en informationsorienteret udvælgelse (Ackerly \& True, 2010, s. 130) af de første fire IPS-teams i Danmark. 13 observationer af teammøderog supervisioner fra 2017-2019 indgår fra den største af arbejdspladserne, med flest konsulenter og brugere. Jobkonsulenter diskuterer her handlemuligheder for brugere $\mathrm{i}$ vanskelige forløb. De giver særlig indsigt i arbejdets indhold samt jobkonsulenternes kollektivt-faglige udvikling (Hammersley \& Atkinson, 2010).

Desuden indgår 16 individuelle biografisk-narrative og semistrukturerede interview med jobkonsulenterne (Wengraf, 2001). Ud fra disse har jeg genereret en personcentreret tolkning af jobkonsulenternes erfaringer med diagnoser. Dermed forstås forskelligheder, og usikkerheden uddybes og præciseres også som ambivalens på individuelt niveau - ikke bare uenighed mellem konsulenterne. Ambivalenserne forstås som ledetråde til immanent kritik af arbejdets modsigelser og interessekonflikter under de aktuelle organisatoriske og samfundsmæssige betingelser (Jakobsen, 2018, s. 33-34; Olsén, 2008, s. 52). De afspejler, jf. analysen, det paradoksale ved at specialisere beskæftigelsesindsatsen for psykiatribrugere og samtidig normalisere dem ved at hævde, at diagnosen er uden betydning for 
deres arbejdsevne. Analysen er en teoretisk forankret, rationel rekonstruktion af dette paradoks (Kalleberg, 2007, s. 151). Begrebet om bivalent kollektivitet forstås, kritisk hermeneutisk, som et teoretisk reflekteret indspil $i$ at udrede de blandede følelser ved at belyse de modsætninger i arbejdet, som skaber dem (Juul, 2010, s. 354). Dermed fremhæves den dynamiske forbindelse mellem jobkonsulenternes arbejdsliv og brugernes situation: Ved at sætte arbejdets "genstand" på begreb bliver det muligt at tolke negative erfaringer som kritiske udsagn, som kan danne grundlag for forbedring af deres situation.

Det betyder ikke, at indblikket i jobkonsulenternes arbejdsliv kan substitueres med et indblik i psykiatribrugeres liv. Denne empiri er en del af en større undersøgelse af IPS (Bonfils, 2019), som viser forskelle til brugernes erfaringer med IPS (Møller, Le Fevre, Andersen, Buus \& Bonfils, 2020). Tre tolkningsmøder med brugerundersøgelsen bekræftede imidlertid, at mange brugere var usikre omkring afsløringen af deres diagnose. Her beskrev en medforsker med brugerbaggrund det ud fra deres empiriske arbejde som; "et dilemma, hvilken fremtid man skaber på arbejdspladsen ved at tale om de psykiske problemer. Man kan komme bagud helt fra begyndelsen". Samtidig var det tydeligt, at jobkonsulenterne kollektivt brugte langt mere tid på at diskutere fordele og ulemper ved at afsløre diagnosen. Det afspejler, at brugerne kun kender deres eget forløb, hvorimod jobkonsulenterne har arbejdet med IPS gennem en årrække og har op til 25 klienter tilknyttet hver. Diagnosens betydning er derfor en mere permanent og tydelig problematik for dem.

Endelig er der afholdt et heldags-forskningsværksted som et erindringsarbejde (Forseth, 2010, s. 13) med ti af jobkonsulenterne, som genererede 35 fortællinger om samarbejdet med arbejdsgiverne. Deltagerne udarbejdede desuden analytiske temaer, og af de ni første temaer, omhandlede fire: afsløringen af diagnoser og tre: forhandlinger om ansættelsesvilkårene. Endelig indgik en deltagervaliderende, første fremlæggelse af analyserne til jobkonsulenterne. Værkstedet er refereret, optaget, gennemlyttet, meningskondenseret og delvis nedskrevet ordret.

I analysen forstås jobkonsulenternes arbejde med IPS som et forsøg på at modvirke den økonomiske marginalisering ved at ændre et kulturelt statushierarki: Ved at omtale brugerne som arbejdstagere, "kandidater", i stedet for som patienter, normaliseres deres status som arbejdskraft. Ved at sætte brugernes ønsker i centrum for arbejdet modvirkes dominans. Ved at synliggøre deres oplevelser og behov modvirkes tabuisering og usynliggørelse. Og jobkonsulenterne kan med en vidensbase $\mathrm{i}$ recovery-litteraturen udfordre fordomme og disrespekt. Erfaringer, hvor diagnosen afsløres over for arbejdsgiverne, sammenlignes med erfaringer, hvor diagnosen ikke afsløres, med fokus på, hvordan det får betydning for jobkonsulenternes position, status og relationer til arbejdsgiverne - og dermed brugernes forløb. De negative erfaringer (Juul, 2010, s. 88) tolkes ud fra begrebet om en bivalent kollektivitet som ansatser til at udbedre psykiatribrugeres kulturelle og økonomiske marginalisering. Til tolkningen af den kulturelle dimension har jeg lagt vægt på afvisninger, som ikke kan begrundes i stillingskrav eller økonomisk værdiskabelse, eksempelvis manglende vilje til dialog, tilskrivning af stereotypiserede egenskaber eller decideret ringeagt og eksklusion. I tolkningen af den økonomiske-strukturelle dimension har jeg lagt vægt på en uoverensstemmelse mellem brugernes behov og arbejdets aktivitetskrav, indhold samt arbejdsdeling og -betingelser - typisk italesat som brugernes egen utilfredshed med arbejdet, eller arbejdsgivernes problematisering af brugernes produktivitet og værdiskabelse. 


\section{Analyse}

Analysen er struktureret omkring dilemmaet: Først beskrives den grundlæggende usikkerhed om (at afsløre) diagnosens betydning. Dernæst beskrives fordele, ulemper og uforudsete risici ved at afsløre og ikke at afsløre diagnosen.

\section{Usikkerheden: normalisering eller scerbehandling?}

Jobkonsulenterne beskriver IPS som et frisættende, lærerigt brud. Brugernes styring mod egne jobønsker gør jobkonsulenternes rolle meningsfuld. Men en forandret arbejdssituation med nye opgaver, brugerstyring og et mere involveret samarbejde med arbejdsgiverne indebærer også en ny usikkerhed. Det handler både om jobkonsulenternes egen tvivl om brugernes formåen, om at kunne (ud)holde brugeres usikkerhed og ambivalens om forløbet på vej mod arbejde (Møller et al., 2020), og (til tider) om arbejdsgivernes manglende tiltro til kandidaterne. Usikkerheden skyldes, at IPS forandrer klienternes position fra at være bærere af en lidelse, patienter, til at være, arbejdstagere - "kandidater". En jobkonsulent med en socialfaglig uddannelse og arbejdserfaring fra beskæftigelsesområdet forklarer:

\begin{abstract}
"For 15 år siden, der sad jeg selv som en socialrådgiver $i$ en arbejdsmarkedsafdeling $i$ en af de små, gamle kommuner (...) Man behøvede slet ikke lave en arbejdsprøvning. Så kunne alle forstå, at de ikke kunne have et arbejde. Og så nu, der forventer vi noesten, at de kan gå i fuldtidsarbejde mange af dem. Og sygdommen den er jo den samme. Så der er jo sket et stort skifte rent politisk, men det er som om, at arbejdsmarkedet ikke rigtig har opdaget det endnu."
\end{abstract}

Fortællingen er eksemplarisk. I metoden er diagnosen ikke længere barriere for at arbej- de. Problemet er, som jobkonsulenten fremhæver, at arbejdsmarkedet ikke har "opdaget det". En anden siger om kontakten med arbejdsgiverne:

"Der er jo noget kontradiktorisk $i$ det her med, at vi går ud og pusher for ordinoere jobs, samtidig med at der er nogen, som har nogen skånebehov, eller nogen erfaringer fra tidligere, hvor vi ved, at vi skal ind og rykke lidt ved rammerne på arbejdspladsen. Der er jo en åbenlys modsaetning $i$ de to ting. Som udgangspunkt: Ordinoert job versus skånebehov."

Det "kontradiktoriske" består i, at den specialiserede støtte med udgangspunkt i diagnoser undergraver normaliseringen og skaber en selvmodsigelse. De hævder eksplicit, at mennesker med psykiske problemer kan arbejde som alle andre; en normalisering. Men implicit antyder kontakten, at de har behov for særlig støtte, hjælp eller hensyn; en differentiering. "Det er noget, man skal sluge som arbejdsgiver, at man skal ansaette det her menneske på fuld løn og ordinoere vilkår. Men man skal alligevel også mingelere lidt med tingene." Dette paradoks bliver aktualiseret i jobsøgningen og skaber tvivl, ambivalens, uenighed og usikkerhed om diagnosernes hensigtsmæssighed i empiriens teammøder, supervisioner og fortællinger. Diagnoser bliver derfor centrale omdrejningspunkter for de professionelles bearbejdning af arbejdets krav om både at lade brugerne bestemme og at samarbejde med arbejdsgiverne. En jobkonsulent fremhæver det for eksempel som et vigtigt analytisk tema, at: "Disclosure [afsløring] er valgfrit. Fordi ... Det er det jo. Og det er heller ikke altid, at det giver mening. Men nogle gange giver det super god mening, at der er disclosure, så vi kan voere med." Betydningen af diagnoser fremstår altså uafklaret; som funktionelle og problematiske for opgaveløsningen. I det følgende viser jeg konsekven- 
serne af at afsløre diagnosen og dernæst af ikke at afsløre den.

\section{Afsløring}

Her vises, hvordan åbenhed om diagnosen $\mathrm{i}$ kontakten til arbejdsgiverne giver mulighed for at tilpasse stillingerne, men risikerer at mobilisere fordomme og stigmatisering.

\section{Tilpasning af stillingernes krav}

Jobkonsulenterne beskriver det som "luksus", hvis kandidaterne er indstillede på at afsløre deres diagnose over for arbejdsgiverne. Så kan de "voere med", hjælpe med at udrede misforståelser og fordomme, håndtere usikkerheder og styrke dialogen. Det vanskelige bliver især at identificere, hvilke arbejdsopgaver eller betingelser, som kan være vanskelige at leve op til. Dette beskrives ofte som en "oversaettel$s e$ " af diagnoser til konkrete behov: "Jo mere konkret man kan gøre det, jo bedre." Mange gode arbejdsgivere er ofte samarbejdsvillige og hjælper så med at tilpasse stillingerne. En medvirkende årsag er, at arbejdsgivere uden velvilje frasorteres allerede i ansøgningsprocessen (jf. Madsen et al., 2016). De prøver derfor at opdyrke kontakt til arbejdsgivere med "personligt kendskab" til psykosociale problemer, eller som de tidligere har haft gode forløb hos. De gode erfaringer med at afsløre diagnosen skyldes, at diagnosen kan gøres til afsæt for at få tilpasset rammerne på arbejdspladsen. Den begrunder særlige behov og giver dermed afsæt for at forhandle om og afhjælpe arbejdets krav og betingelser (Fraser, 2013, s. 54). Denne forløsning af usikkerheden om psykiatribrugeres arbejdsevne består i, at den kulturelt forankrede forskelssætning bekræftes, så den kan lægges til grund for en politisk-økonomisk omfordeling på arbejdspladsen. Denne afklaring af brugernes situation er hensigtsmæssig, endda nødven- dig, for brugere med behov for tilpasning af stillingernes indhold og betingelser.

\section{Risikoen for stigma}

Jobkonsulenterne oplever imidlertid også diagnoserne som problematiske forskelssætninger. En af IPS-konsulenterne fortæller om et forløb, hvor en kandidat bliver afvist af en arbejdsgiver på grund af sin diagnose, men derefter bliver ansat i samme stilling et andet sted. Den første arbejdsgiver sagde, at:

\begin{abstract}
"'(...) sådan en ville jeg aldrig nogensinde ansaette. (...)'. Så vi blev enige om, at den noeste arbejdsgiver, vi så kontaktede, der skulle jeg undlade at fortoelle, at hun havde skizofreni. Og jeg kan også godt tvivle på, at den arbejdsgiver, hun så er hos nu, så ville have tilbudt hende det [job]. Og hun klarer det bare SA fint."
\end{abstract}

Fortællingen illustrerer, hvordan afsløringen af diagnosen kan aktivere en kulturelt forankret stigmatisering, på trods af at diagnosen ikke har klare implikationer for kandidatens arbejdsevne på det pågældende arbejdsområde. På teammøder er administration af information derfor et fremtrædende tema. Konsulenterne fortæller om at "kigge på væggene", når de skal have møder, eller tilbageholde visitkort for ikke at afsløre, at de er en specialiseret enhed. Et tilbagevendende tema i supervisioner er længerevarende arbejdsløshed; "huller på $c v^{\prime} e t "$. Selv om den burde kunne forklare tidligere langtidsarbejdsløshed, så er det en ulempe at bruge diagnosen som forklaring. Og selv om man ikke kan udlede hverken den nuværende arbejdsevne eller helbredssituation fra diagnosen, så mindsker den kandidaternes status yderligere. En lavstatusgruppe, "de arbejdsløse", bliver forbundet med en anden lavstatusgruppe, "de psykisk syge." Arbejdsgi- 
verne forventer, at denne "tunge" gruppe er meget vanskelig at integrere. Dette afspejler et bredere samfundsmæssigt statushierarki om produktivitet og afhængighed (Fraser 1997 , s. 137; 2013, s. 102). Alene tilknytningen til jobcenteret betyder, at kandidaternes status som arbejdskraft er udfordret, og at de står i en svagere forhandlingsposition på arbejdsmarkedet. Korttidsarbejdsløse har højest status. Langtidsarbejdsløse har lavere status. Jobkonsulenterne oplever desuden ofte, som i eksemplet ovenfor, hvordan svære diagnoser, som for eksempel skizofreni (Mosegaard, Vedel, Hald \& Marie Boje, 2018, s. 12), giver lavere status end lette diagnoser (Jacobsen et al., 2010, s. 13). Systematisk selvmedicinering ved stofbrug eller afhængighed er samtidig værre end sygdom alene. Lavest status har de af deres klienter, som er langtidsarbejdsløse med en svær psykiatrisk diagnose og brug af rusmidler. Diagnosen indgår altså i en positionering af mennesker i beskæftigelsesindsatsen, som giver "tilskrevne egenskaber, som leder til tydelige forskelle i positionen på arbejdsmarkedet", på trods af at de ikke beskriver "nogen af arbejdskraftens egenskaber eller brugsværdi for produktionsprocessen" (Offe, 1984, s. 36, min fremhævning).

\section{Status: drivkraft for marginalisering}

Den citerede fortælling illustrerer dermed, hvordan kulturelle statushierarkier bidrager til at opretholde en uretfærdig økonomisk marginalisering. Når man påbegynder arbejdssøgningen med afsløring af diagnosen, så afskæres mange fra et arbejde, som de fint kan varetage. I IPS er diagnosen inklusionskriterie for en offentligt foranstaltet beskæftigelsesindsats, som skal modvirke økonomisk marginalisering. Det er en "affirmativ" (Fraser, 2010, s. 239) strategi i den forstand, at det bekræfter eksisterende kulturelle statushierarkier om produktivitet og normalitet: Psykiatribrugeres arbejdsevne bli- ver et individuelt spørgsmål knyttet til deres diagnose, og de fremstår fortsat som mindre produktive. Denne affirmative omfordelings praktiske anerkendelseseffekt kan, som vi ser i arbejdet med IPS, være en "sekundær stigmatiseringsdynamik" (Fraser, 1997, s. 25), som skader det ønskede mål om ligestilling. Kulturelle statushierarkier kan altså være årsag til økonomisk marginalisering, hvilket bidrager til at forklare de professionelles ambivalenser om at afsløre diagnosen.

\section{Ingen afsløring}

Her vises, hvordan tilbageholdelse af information om diagnosen i kontakten til arbejdsgiverne substituerer problemer med stigmatisering med en risiko for dominans.

\section{Ofte en succes}

Den sekundære stigmatiseringsdynamik skaber et pres for ikke at afsløre diagnosen. "CV-arbejde" er kommet til at stå centralt for konsulenterne - selv om det ikke forskrives i IPS. Det er en hjælp til at lade brugerne selv kontakte arbejdsgiveren, uden at jobkonsulenterne behøver at være til stede - og dermed afsløre diagnosen. Her "oversættes" de svære diagnoser til konkrete støttebehov eller lettere diagnoser, som stress og angst. Der skabes forklaringer på overvindelse af problemer. Appetit på arbejdslivet fremhæves. Og informationer, som giver bredere samfundsmæssig anerkendelse som frivilligt arbejde og fritidsinteresser understreges. Dermed undgås fordomme og stigmatisering, og hovedvægten bliver i stedet på den enkeltes motivation for at arbejde, som er en afgørende faktor for, om folk kommer i beskæftigelse (Drake et al., 2012). De succesfulde jobkonsulenter i en specialiseret indsats for psykiatribrugere oplever ofte at lykkes med at søge arbejde, uden at diagnosen afsløres. En anden forløsning af diagnosens betydning 
består altså i, at statushierarkier adskilles fra arbejdspladsen. Dermed forbigås unødvendig disrespekt i form af stigmatisering og diskrimination. Dette er hjælpsomt for de psykiatribrugere, som uden særlig tilpasning kan varetage det arbejde, de søger.

\section{Dynamisk stabilisering}

Ikke desto mindre er der ofte et spændingsforhold mellem brugernes ønsker og så en strukturel arbejdsdeling med særlige produktivitets- og konkurrencekrav på det ønskede arbejdsområde. En konsulent fortæller om hendes klient, som skal til samtale i sin "drømmestilling":

"Det er 37 timer, og hun ved, at hun ikke kan arbejde 37 timer. Men hun ville vildt gerne have stillingen. Og der bliver aldrig opslået stillinger her. 'Skal jeg tage til samtale og fortoelle dem om, at jeg er syg? Og så er jeg oppe mod fem kandidater, som ikke er syge?' Hun ville jo godt kunne varetage stillingen, men nok kun på 25 timer. Og hvor meget kan man tillade sig at gå ind og kroeve, når man er fagligt inde $i$ et felt, hvor der er så mange dygtige, og det kraever noget saerligt? (...) Der er mange, der er ligeglade med området, hvorimod vilkårene er vigtige. Men her er det arbejdsområdet, og de vilkår der er her kan bare ikke mødes [med kandidatens behov]. Og hvad gør jeg så som IPS-konsulent? For jeg kan jo ikke gå ind og skabe, nødvendigvis, en stilling... Det bliver jo så målet. Det må jeg jo prøve. Men det er eddermame svoert. Fordi hun er meget specifik $i$ forhold til arbejdsopgaverne og arbejdsområdet. Og samtidig kritisk $i$ forhold til, hvad det ikke må vaere?"5

Denne kandidat ønsker et "specifikt" arbejde, og jobkonsulenten oplever at skulle "skabe en stilling". Uden magt til at påvirke betingelser for ansættelsen, identificerer hun sig med arbejdstagerens dilemma: Det opleves som risikabelt at afsløre diagnosen og "tillade sig at gå ind og kræve" en tilpasning af stillingen. Kandidatens ønsker for sit arbejde opleves samtidig som "specifikt" og "kritisk". Beskrivelsen afspejler det belastende ved kravet om at skabe en specifik, tilpasset stilling uden at give en klar begrundelse. Ofte ender den manglende afsløring ikke i en bæredygtig ansættelse, men i en form for dynamisk stabilisering: Kandidaterne vælger, ved problemer, at finde et andet, mere "realistisk" arbejde. ${ }^{6}$ Jobkonsulenterne kalder dette at afslutte ansættelser "før tid - efter eget ønske". En god del har mere end tre ansættelser i et IPS-forløb, og nogen mange flere. Med princippet om brugerstyring og deres gode arbejdsbetingelser er det stadig meningsfuldt for jobkonsulenterne at skabe en relation med håb, støtte og tillid til klienternes evner (Topor \& Ljungberg, 2016), som kan være en forudsætning for at kaste sig ud i nye stillinger på et dynamisk og differentieret arbejdsmarked med mange jobtilbud. Denne dynamiske stabilisering er "effektiv"; flere kommer i arbejde.

\section{Risikoen for dominans}

Hyppige skift i ansættelser giver imidlertid dårligere forudsætninger for at opbygge en bæredygtigt, kontekstuelt forankret produktivitet, som leder til fastansættelse (jf. Madsen et al., 2016). I en faglig diskussion siger en konsulent i forlængelse af en fortælling om en klient, som ikke ville afsløre sin diagnose og endte med en fyring:

"Det er et stort problem (...) Vi har ikke altid kontakt med arbejdsgiverne. Det er jo ikke altid os, som har skaffet jobbet. Så bliver det mere sådan 'behind the scenes'. Men hvis vi ikke har noget sted at mødes med folk, så kan det voere svoert at hioelpe dem." 
Udsagnet møder enighed. Jobkonsulenterne deler en erfaring af at stå magtesløse, når kandidaterne ikke afslører deres diagnose og arbejder "over evne". Jobkonsulenternes arbejde bliver en hjælp, 'behind the scenes', til at søge arbejde - men ikke til at voere i det. De afskæres ikke bare fra at udfordre statushierarkier, men også fra at forandre de krav på arbejdsmarkedet, som måske ville kunne hjælpe brugerne til at være i det $ø$ nskede arbejde. Jobkonsulenternes ambivalente forhold til at afsløre diagnosen skyldes altså ikke alene mobiliseringen af uretfærdige statushierarkier. I så fald kunne man blot undlade at afsløre diagnosen. Det skyldes også en risiko for, at arbejdstagernes problemer usynliggøres (Akabas \& Gates, 2008, s. 180). Resultatet af den manglende afsløring af diagnosen kan blive dominans: At brugerne bliver tvunget til at underkaste sig de dominerende forestillinger om produktivitet og lade sig udbytte på de givne vilkår. Eller, som i tilfældet ovenfor, eksklusion.

\section{Udbytning forankrer statushierarkier}

Endelig oplever jobkonsulenterne vanskelige forhandlinger selv uden afsløringer:

Jobkonsulenten har fundet en stilling til sin kandidat. Endelig ringer arbejdsgiveren, men tilbuddet om ansoettelse kommer ikke. "Men mangler I en ansat? Vi anbefaler jo ikke praktikker, men hvis det kan saette en fod $i$ døren... Praktikken kan bare ikke voere et mål i sig selv." Svaret er uklart. "Han skal voelge selv. Han vil gerne arbejde. Og det er jo hans ret at voelge selv. Så jeg vil give ham tilbuddet. Hvis I har muligheden, og han gerne vil. Men hvis I gav ham en ansaettelse, så kunne jeg muligvis skaffe noget faglig supervision til ham. Nok ikke 6 måneder. Men i opstartsperioden. Kunne det voere noget? Det vil voere en bedre mulighed, synes jeg. Det kunne vi jo snakke om." De aftaler at mødes alle tre. (feltnote)
I samtalen forsøger arbejdsgiveren at få en praktikplads i stedet for en reel ansættelse. Det er typisk, da det fjerner usikkerhed i en tilpasningsfase (jf. Madsen et al., 2016). Efter samtalen fortæller jobkonsulenten, at arbejdsgiveren ofte spørger ind til kandidatens problemer: "Hvad for nogen problemer har han? Det er en anden formulering, man ofte hører, når man ringer på vegne af nogen. Hvad for nogen problemer har han, siden han beder dig om at ringe for sig?" Arbejdsgivernes udfordrer altså normaliseringen af arbejdstagerne, hvis ikke de selv informerer om særlige behov. En kandidat fik først betalt mentorstøtte, men endte alligevel med at blive fyret:

"Der endte jeg i sådan noget forhandling med; med hvor meget kunne vi tilbyde i mentor-støtte, og hvor meget kan vi tilbyde... (...) Fordi de blev ved med at sige, at de kunne rigtig godt lide ham her, og de ville rigtig gerne give ham jobbet. Men, han var ikke produktiv. (...) Der bliver det sådan en underlig forhandling, som jeg... synes var ubehagelig."

Ubehaget afspejler et krav om at være på god fod mellem to parter i en interessekonflikt. Det diskuteres ofte, om der er tale om reel usikkerhed eller det blot er led i en forhandling om at få dem til at acceptere dårligere ansættelsesvilkår. Selv når klienternes produktivitet ikke er nedsat, er det i arbejdsgivernes strukturelt definerede interesse at reintroducere og betone statushierarkierne for at mindske udgifterne. Her bliver en anden "ond cirkel" (Fraser, 1997, s. 24) altså synlig: Økonomisk udbytning opretholder kulturelle statushierarkier.

\section{Konklusion}

Denne artikel viser, hvordan psykiatribrugeres beslutning om (ikke) at afsløre deres diagnose får betydning for jobkonsulenters arbejde med at integrere dem på arbejdsmar- 
kedet. Diagnoser er arbejdsredskaber for psykiatrisk behandling og udtrykker et vidensfelt med særlige problemforståelser: Logikken ved at specialisere beskæftigelsesindsatsen er, at en eventuel psykiatrisk diagnose er det primære kendetegn ved en arbejdsløs person - som forklarer vedkommendes problemer og berettiger dem til støtte.

I den specialiserede beskæftigelsesindsats er diagnosens betydning ikke så entydig. Jobkonsulenterne knytter i højere grad an til idealer om brugerstyring og ligestilling af deres klienter end til diagnoserne. Og på trods af de gode resultater med et specialiseret arbejde for psykiatribrugere fremstår jobkonsulenternes erfaringer med diagnoserne ambivalente. Analysen af ambivalenserne viser, med afsæt i Frasers begrebsapparat, hvordan diagnoser bliver omdrejningspunkter for status- og ressourcekampe i forhandlinger med arbejdsgiverne. For nogen brugere bliver diagnosen en vigtig forklaring på og legitimering af deres behov for tilpasning og støtte: De professionelle kan deltage på arbejdspladsen, udfordre arbejdsgivernes fordomme eller bekymringer, fjerne risici ved at tilføre ansættelsen ressourcer og konkretisere diagnosens implikationer for tilrettelæggelsen af arbejdet. For andre adskilles deres diagnose fra arbejdssøgningen, og dens betydning for arbejdssøgningen mindskes. Det kan lede til en normalisering af deres individuelle status som arbejdskraft.

Processen er imidlertid hverken lineær eller konfliktfri. Forløbene er forskelligartede og komplekse. Ved at forstå psykiatribrugere som en bivalent kollektivitet kan man forklare, hvorfor valget om at afsløre diagnosen udgør et dilemma: Enten reproduceres kulturelle statushierarkier for at retfærdiggøre en økonomisk omfordeling i form af særlig støtte og tilpasning på arbejdspladsen - hvilket indebærer en risiko for stigmatisering; eller også forbigås kulturelle statushierarkier, hvilket ofte giver arbejde, men indebærer en risiko for, at eventuelle problemer relateret til arbejdsprocessens krav og betingelser usynliggøres. Disse kan så blive årsag til problemer, hyppigt jobskifte eller decideret eksklusion.

Den analytiske adskillelse af kulturel og økonomisk marginalisering er nødvendig for at kritisere manglende ligestilling af psykiatribrugere på arbejdsmarkedet. Den bryder op i den tætte kobling mellem normalitet, sundhed og produktivitet, som ekskluderer psykiatribrugere. I modsat fald kan fordomme blive knyttet til arbejdsgivernes bekymring om produktiviteten (jf. Madsen et al., 2016), hvilket kan komme til at trumfe deres (ofte mange og væsentlige) gode hensigter. Kritikken af kulturelt forankret stigmatisering må netop ske på grundlag af en antagelse om, at det er muligt at adskille den fra de reelle problemer, der kan være med at deltage $\mathrm{i}$ arbejdsprocesserne.

Adskillelsen udgør også en ressource til at vurdere individuelle personers situation i det fremadrettede arbejde med at integrere gruppen på arbejdsmarkedet. En succesfuld ansættelsesproces er ikke nødvendigvis udtryk for lighed i deltagelse. Men man kan spørge, om problemer relaterer sig til stillingernes krav eller til mere løsrevne kulturelle dynamikker. Og man kan adskille brugere med behov for tilpasning af arbejdsprocesserne, fra brugere som alene er underlagt statushierarkier. Den første gruppe kan have gavn af at afsløre deres diagnose med henblik på at få støtte til (oversættelsen til) specifikke skånehensyn på arbejdspladsen - i modsætning til abstrakte fordomme. For de andre er det mindre indlysende, at diagnoser er et nødvendigt og tilstrækkeligt afsæt for jobsøgningen. Adskillelsen kan dermed anvendes til at diskutere, forstå og støtte brugerne i deres komplekse forløb.

Mest væsentligt gør forståelsen af psykiatribrugere som en bivalent kollektivitet det muligt at udpege og forklare komplekse 
marginaliseringsdynamikker: Kulturel og økonomisk forankret ulighed spiller sammen, når afsløringen af diagnosen mobiliserer fordomme og afskærer psykiatribrugere fra at deltage på arbejdsmarkedet: Disrespekt opretholder økonomisk marginalisering. Eller når arbejdsgiverne opretholder eller reaktualiserer psykiatribrugeres lavere status i forhandlinger om ansættelsesvilkår: Økonomisk betingede interessekonflikter opretholder statushierarkier. Udpegningen af komplekse marginaliseringsdynamikker kan bidrage til at forstå, hvorfor intentioner om inklusion er vanskelige at indfri i praksis.

Endelig kan udpegningen af komplekse marginaliseringsdynamikker etablere dialog på tværs af en dominerende institutionel (og til dels forskningsmæssig) opsplitning i et psykiatrifagligt og et beskæftigelsesrettet perspektiv (jf. Bengtsson \& Ørkeby Gregersen, 2013; Bonfils, 2019). En for skarp arbejdsdeling risikerer at isolere økonomisk og kulturelt forankrede uretfærdighedsdynamikker fra hinanden - og miste blikket for deres indbyrdes samspil.

I forhold til et fokus på at forbedre beskæftigelsesindsatsen bliver det vigtigt at fastholde konflikten mellem psykiatribrugeres særlige behov og arbejdsmarkedets krav. Ofte må og skal arbejdsprocesserne(s rammer) tilpasses, hvis (alle) psykiatribrugere skal i arbejde. Det er derfor ikke tilstrækkeligt at skabe et stærkere samarbejde mellem beskæftigelsesindsats og offentlige jobkonsulenter. Integration kræver inkluderingskompetence (Frøyland et al., 2019) til at udvikle både behov og stillingskrav. Denne analyse belyser ikke systematisk, hvilke behov som typisk er sat under pres, hvilket peger på et behov mod mere forskning. Ellers risikerer beskæftigelsesindsatsen at styrke arbejdsgivernes magtposition og definitionsret til produktivitet. Konkurrence uden hensyn til psykiske problemer indebærer en risiko for, at psykiatribrugere må underkaste sig dominerende koblinger af produktivitet og normalitet. I værste fald usynliggøres deres behov, og de ender, fortsat, med en lavere deltagelse end andre grupper på arbejdsmarkedet. Det skaber ikke lighed i deltagelse.

For en psykiatrifaglig forskning (Drake et al., 2012) rejser analysen spørgsmålet, om diagnoser nødvendigvis er det rette afsæt for at organisere beskæftigelsesindsatsen: Potentialerne ved en specialiseret beskæftigelsesindsats er at udfordre de dominerende statushierarkier gennem aftabuisering, oplysning og anerkendelse. Men afsættet i diagnoser risikerer trods eksplicitte ambitioner om en normalisering at give arbejdsgiverne et grundlag for at reproducere dominerende statushierarkier. Dels fordi diagnoser ikke altid giver hold om brugernes behov i forhold til specifikke stillinger. Dels fordi det er vanskeligt at transformere de kulturelle statushierarkier, som knytter forestillinger om produktivitet på arbejdsmarkedet tæt sammen med normalitet og sundhed, når psykiatrisk forankrede forskelssætninger netop gøres til afsæt for organiseringen af beskæftigelsesindsatsen. Og endelig fordi arbejdsgiverne har en strukturelt defineret interesse $i$ at opretholde statushierarkierne i forhandlinger om ansættelsesbetingelserne. Den psykiatrifaglige tilgang forsøger at udbedre økonomiske uretfærdigheder ud fra en rent kulturel opskrivning af psykiatribrugernes status. Men ud fra en forståelse af psykiatribrugere som en bivalent kollektivitet har problemet også økonomisk-strukturelle rødder. En langsigtet afmontering af statushierarkier nødvendiggør derfor en mere dybdegående bearbejdning af de interessekonflikter, og forståelser af produktivitet, som udspiller sig i forhandlinger om stillingerne. I denne proces er lovende metoder som IPS vigtige, men indledende, skridt. Det fremstår fortsat som en vigtig uforløst udfordring at understøtte alle psykiatribrugeres deltagelse på arbejdsmarkedet. 


\section{LITTERATUR}

Ackerly, B. A. \& True, J. (2010). Doing feminist research in political and social science. Palgrave Macmillan.

Akabas, S. H. \& Gates, L. B. (2008). A social work role. Administration in Social Work, 23(3,4), 163-184. https://doi.org/10.1300/ J147v23n03_10

Baadsgaard, K., Jørgensen, H., Nørup, I. \& Olesen, S. P. (2012). Fra klientorienteret arbejde til administrativt arbejde - ændringer i den faglige praksis og kvalificering på det beskæftigelsespolitiske område. Tidsskrift for Arbejdsliv, 14(4), 30-46.

Bengtsson, S. \& Ørkeby Gregersen, S. (2013). Integrerede indsatser over for mennesker med psykiske lidelser - en forskningsoversigt. SFI - Det Nationale Forskningscenter for Velfærd.

Bonfils, I. S. (2019). Implementering af IPS - individuelt planlagt job med støtte. København: Institut for Socialrådgiveruddannelse, Københavns Professionshøjskole.

Borg, V., Nexø, M. A., Kolte, I. V. \& Andersen, M. F. (2010). Hvidbog om mentalt helbred, sygefravoer og tilbagevenden til arbejde. København: Det Nationale Forskningscenter for Arbejdsmiljø (NFA).

Drake, R. E., Bond, G. R. \& Becker, D. R. (2012). Individual Placement and Support: An Evidence-Based Approach to Supported Employment. Oxford University Press. https://doi.org/10.1093/acprof:oso/9780199734016.001.0001

Eplov, L. F. \& Christensen, T. N. (2018). Resultater fra IPS projektet. København: STAR.

Flyvbjerg, B. (2006). Five Misunderstandings About Case-Study Research. Qualitative Inquiry, 12(2), 219-245. https://doi. org/10.1177/1077800405284363

Forseth, U. (2010). Ambivalenser i frontlinjearbeid. Tidsskrift for Arbejdsliv, 12(3), 9-24. https://doi.org/10.7146/tfa.v12i3.108865

Fraser, N. (1989). Talking about Needs: Interpretive Contests as Political Conflicts in Welfare-State Societies. Ethics, 99(2), 291-313.

Fraser, N. (1995). From redistribution to recognition? Dilemmas of justice in a 'post-Socialist' age. New Left Review, 212, 68-93. https://doi. org/10.1002/9780470756119.ch54

Fraser, N. (1997). Justice Interruptus - Critical Reflections on the "Postsocialist" Condition (1.). Routledge.

Fraser, N. (2007). Feminist Politics in the Age of Recognition: A Two-Dimensional Approach to Gender Justice. Studies in Social Justice, 1(1).

Fraser, N. (2013). Fortunes of Feminism: From State-Managed Capitalism to Neoliberal Crisis (1. udg.). Verso. https://doi.org/10.1007/s10691014-9258-0

Frøyland, K., Schafft, A. \& Spjelkavik, Ø. (2019). Tackling increasing marginalization: Can support-side approaches contribute to work inclusion? I H. Hvid \& E. Falkum (Red.), Work and Wellbeing in the Nordic Countries (1. udg., s. 194-215). Routledge. https://doi. org/10.4324/9781351169967-14

Hammersley, M. \& Atkinson, P. (2010). Ethnography: principles in practice. Routledge.

Jacobsen, C. B., Martin, H. M., Andersen, S. L., Christensen, R. N. \& Bengtsson, S. (2010). Stigma og psykiske lidelser - som det opleves og opfattes af mennesker med psykiske lidelser og borgere i Danmark.

Jakobsen, A. (2018). Faglighed, mening og ambivalens i prekært akademisk arbejde. Tidsskrift for Arbejdsliv, 20(1), 30-46. https://doi. org/10.7146/tfa.v20i1.108196

Juul, S. (2010). Solidaritet - anerkendelse, retfoerdighed og god dømmekraft: en kritisk analyse af barrierer for sammenhoengskraft $i$ velfoerdssamfundet (1.). Hans Reitzel.

Kalleberg, R. (2007). A reconstruction of the ethos of science. Journal of Classical Sociology, 7(2), 137-160. https://doi. org/10.1177/1468795X07078033

Ladegaard, Y., Thisted, C. N., Gensby, U., Skakon, J. \& Netterstrøm, B. (2017). Hvordan håndterer danske arbejdspladser arbejdsrelateret sygdom? Tidsskrift for Arbejdsliv, 19(4), 92-106. https://doi.org/10.7146/tfa.v19i4.109054

Larsen, F. \& Andersen, N. A. (2019). Fra Socialpolitik til Beskæftigelsespolitik - Er beskæftigelse 
for alle? Tidsskrift for Arbejdsliv, 21(1), 11-28. https://doi.org/10.7146/tfa.v9i4.108629

Larsen, M. R. \& Larsen, M. (2017). Handicap, beskæftigelse og uddannelse i 2016 (SFI 17:15). I SFI - Det Nationale Forskningscenter for Velfoerd, 17,15 .

Link, B. G. \& Phelan, J. C. (2001). Conceptualizing Stigma. Annual Review of Sociology, 27(1), 363-385. https://doi.org/10.1146/annurev. soc. 27.1.363

Madsen, M. B., Søbjerg Nielsen, U., Ehrenreich, R., Habekost, A. M. \& Ørnbøl, J. K. (2016). Fra Udsat til Ansat - set fra et arbejdsgiverperspektiv (1.). Væksthusets Forskningscenter.

Møller, J. R., Le Fevre, S. R., Andersen, J. E., Buus, E. B. \& Bonfils, I. S. (2020). At blive behandlet som et menneske" - et studie af brugernes erfaringer med Individuelt planlagt job med støtte - IPS. København: Institut for Socialrådgiveruddannelse, Københavns Professionshøjskole

Møller, M. Ø. \& Stone, D. (2013). Disciplining Disability under Danish Active Labour Market Policy. Social Policy and Administration, 47(5), 586-604. https://doi.org/10.1111/j.14679515.2012.00835.x

Mosegaard, L., Vedel, P., Hald, N. \& Marie Boje, M. (2018). Oplevelse af stigmatisering blandt mennesker med psykisk sygdom (1.). VIA UC.

Nielsen, H. K. (2018). Aesthetics and political culture in modern society (1. udg.). Routledge. https://doi.org/10.4324/9781351123181

Nielsen, M. H. (2015). Det aktive menneskes triumf? - en analyse af de omfattende forandringer af kategoriseringen af kontanthjælpsmodtageren. Tidsskrift for Arbejdsliv, 17(1), 44-60.
Offe, C. (1984). Contradictions of the Welfare State (J. Keane (red.)). Hutchinson.

Olsén, P. (2008). "Hvis vi bare ku få fred til at passe vores arbejde" - Om mening, forandring og psykisk arbejdsmiljø. Tidsskrift for Arbejdsliv, 10(4), 43-58.

Rose, N. (2019). Our Psychiatric Future (1.). Polity Press.

Spjelkavik, Ø., Enehaug, H., Klethagen, P. \& Schafft, A. (2020). Arbeidsinkludering og mentor Inkluderingskompetanse gjennom samskaping (1. udg.). Arbeidsforskningsinstituttet AFI.

STAR. (2020). Førtidspension. Jobindsats.dk. https://www.jobindsats.dk/jobindsats/sv/ DatabankViewer/ChooseMeasure?BenefitGroupId $=\mathrm{Y} 10$

Thornicroft, G., Brohan, E., Rose, D., Sartorius, N. \& Leese, M. (2009). Global pattern of experienced and anticipated discrimination against people with schizophrenia: a cross-sectional survey. The Lancet, 373(9661), 408-415. https://doi.org/10.1016/S0140-6736(08)61817-6

Topor, A. \& Ljungberg, A. (2016). "Everything is so relaxed and personal" - The construction of helpful relationships in individual placement and support. American Journal of Psychiatric Rehabilitation, 19(4), 275-293. https://doi.or g/10.1080/15487768.2016.1255276

Wengraf, T. (2001). Qualitative Research Interviewing: Biographic Narrative and Semi-Structured Methods (Sage (red.)). SAGE.

Yin, R. K. (2006). Case Study Reserach - Design and Methods. I Clinical Research (Bd. 2). https://doi.org/10.1016/j.jada.2010.09.005 


\section{Noter}

1. Det er en vigtig principiel pointe, i forlængelse af synet på forskelssætninger i denne artikel, at den proces, som diskuteres under betegnelsen 'disclosure' af jobkonsulenterne, er forskelligartet og modsætningsfuld: Den indebærer dimensioner af åbenhed, synliggørelse, oplysning, aftabuisering og offentliggørelse.

2. Artiklen er baseret på en delundersøgelse af jobkonsulenternes arbejdsliv i forskningsprojektet "Individuelt Planlagt Job med Støtte Implementering, organisering, erfaring", som også indeholder en undersøgelse af implementeringen af metoden i danske velfærdsinstitutioner (Bonfils, 2019) samt af brugernes erfaringer med støtten og en undersøgelse af brugernes erfaringer (J. R. Møller et al., 2020). Analysen er kvalificeret af alle involverede.
Undersøgelsen er finansieret af Sundheds- og Ældreministeriet 2016 ved hjælp af midler fra Regeringens forskningspulje til gavn for mennesker med psykiske lidelser.

3. Svær psykiatrisk diagnose er i litteraturen om individuelt planlagt job med støtte defineret som skizofreni, bipolar lidelse eller svær depression.

4. I den interne terminologi i litteraturen bag metoden hedder process-evalueringerne 'fidelitetsmålinger', og performance-målingerne hedder 'effektmålinger'.

5. I indsatsen IPS følger jobkonsulenterne i udgangspunktet brugernes præferencer og valg så vidt muligt.

6. Statistisk set er det oftere ufaglært, manuelt arbejde uden ledelsesopgaver (jf. Røn Larsen og Larsen, 2017, s. 130).

Søren Salling Weber, ph.d.-studerende, cand.soc. Institut for Mennesker og Teknologi, Roskilde Universitet e-mail: ssweber@ruc.dk 